\title{
Physico-Chemical Properties of Soil as Influenced by Integrated Nutrient Management in Noni (Morinda citrifolia), Grownas a Mixed Crop in Coconut Garden
}

\author{
Sarat Chandra Sahoo ${ }^{1}$, Jinita Barwa ${ }^{1}$, Gopa Mishra ${ }^{\text {* }}$ and Susant Kumar Pattanik ${ }^{2}$ \\ ${ }^{1}$ Department of Fruit Science and Horticulture Technology, ${ }^{2}$ Department of Soil Science and \\ Agricultural Chemistry, CA, OUAT, Bhubaneswar, India \\ *Corresponding author
}

\begin{abstract}
A B S T R A C T
An experiment was carried out at All India Coordinated Research Project on Palms, OUAT, Bhubaneswar during 2013-2014 to study the effect of integrated nutrient

\section{Keywords}

Fruit nutrition, INM, Leaf nutrition, Noni Nutrient uptake, Yield

Article Info

Accepted:

04 April 2018

Available Online:

10 May 2018 management on physico-chemical properties of soil as well as on plant tissue of Noni (Morinda citrifolia L.) grown as a mixed crop in coconut garden. The experiment was conducted on a ten years old noni plantation with 7 treatments replicated thrice in a RBD. The treatments were T1: control, T2: $100 \% \mathrm{RDF}, \mathrm{T} 3: 75 \% \mathrm{RDF}+25 \%$ organic, T4: $50 \%$ $\mathrm{RDF}+50 \%$ organic, $\mathrm{T} 5: 25 \% \mathrm{RDF}+75 \%$ organic, $\mathrm{T} 6: \mathrm{RDF}$ through organics (FYM+ in situ green manuring+ biofertilizer), T7: RDF from organics (FYM+ in situ green manuring + Vermicompost). Observations were recorded on plant biometrical parameters, leaf and fruit nutrient concentrations, yield, uptake of nutrients by noni crop and post harvest soil physico-chemical parameters. Based on the soil test report, 50\% inorganic nitrogen integrated with 50\% nitrogen through FYM (T4) was found more effective in resulting higher uptake of $\mathrm{N}(28.42 \mathrm{~kg} / \mathrm{ha})$, moderate uptake of $\mathrm{P}(3.95 \mathrm{~kg} / \mathrm{ha})$ and $\mathrm{K}(30.00 \mathrm{~kg} / \mathrm{ha})$ which was also reflected in terms of higher concentration of $\mathrm{N}(2.16 \%), \mathrm{P}(0.30 \%)$, and $\mathrm{K}$ $(0.28 \%)$ in the fruit tissue.
\end{abstract}

\section{Introduction}

Noni (Morinda citrifolia L.) is an underexploited fruit crop, better known as a medicinal plant due to the Xeroxine content which acts as a brain stimulant. Besides other medicinal properties noni is believed to be a good appetizer. Morinda citrifolia L. belongs to family Rubiaceae, classified as a small evergreen shrub or tree, plants are generally less than 10 feet height occasionally rising to 20 feet and largely confined to the tropical areas like west cost of India, A-N islands, Australia, Hawaii, South specific and Caribbean islands. Recently an unidentified Morinda species with large and leathery leaves was reported in the Dhandakaranya forest area of Malkanagiri district in Odisha (Singh et al., 2007). Fruits (botanically syncarp) are yellowish white fleshy, long and soft, fetid when ripe. The crop is easy to grow and least infested by diseases and pests. Noni is seen throughout the coastal region along fences and road sides due to its wider adaptability to 
hardy environment. It can be grown in variety of soils both in costal and interior climatic condition. It can be grown as a sole or intercrop in different fruit plantations.

Different workers shown that integrated use of organic manures and biofertilizers with or without chemical fertilizers could buildup the available nutrient status of soil and would be more effective than the use of chemical fertilizers under integrated nutrient management system. Chemical fertilizer alone leads to the deterioration of soil characteristics and fertility and might lead to the accumulation of heavy metals in plant tissues, affecting the nutritional value and edibility of fruit (Shimbo et al., 2001).

Keeping above facts in view a study was carried out to know the effect of integrated nutrient management on growth, fruit quality and yield of noni crop and as well as on the soil physiological properties, when grown as a mixed crop in coconut garden under Odisha condition. Supplementation of inorganic fertilizers (Recommended dose) by organic nutrient was carried out to observe the effect of different INM on both soil and plant.

\section{Materials and Methods}

An experiment was carried out on a ten years old noni plantation at All India Coordinated Research Project on palms, OUAT, Bhubaneswar to study the effect of integrated nutrient management on noni crop. Noni was raised as an intercrop in the coconut garden. Prior to the experiment the soil nutrient status was checked. The experiment was laid in RBD with 7 Treatments combination replicated thrice. The various treatment were like $\mathrm{T}_{1}$ (control), $\mathrm{T}_{2}$ (100\% NPK recommended dose), $\mathrm{T}_{3}(75 \% \mathrm{NPK}$ of RDF from $+25 \% \mathrm{FYM}$ of RD), $\mathrm{T}_{4}(50 \% \mathrm{NPK}$ of RDF $+50 \% \mathrm{FYM}$ of RD), $\mathrm{T}_{5}(25 \% \mathrm{NPK}$ of RDF $+75 \% \mathrm{FYM}$ of $\mathrm{RD}), \mathrm{T}_{6}\{100 \%$ NPK of RDF from organic
(FYM, GM and BFs) $\}, \mathrm{T}_{7}\{100 \%$ NPK of RDF from organic (FYM, GM and VC) $\}$. Data on leaf nutrient status during monthly interval, fruit nutrient status, nutrient uptake, response due to various treatment combination, yield and post harvest soil status were recorded. The estimation of nitrogen, and potash was conducted by modified Kjeldal method and flame-photometer using neutral normal ammonium acetate extract respectively (Jacson, 1973). The available phosphors and organic carbon was estimated by Bray's 1 method and Walkley and Black's rapid titration method respectively (Page et al., 1982).

\section{Results and Discussion}

Leaf nutrient status of noni showed a decreasing trend during the monthly observation. In the month of March the maximum nitrogen content was found 4.80 per cent $\left(\mathrm{T}_{5}\right)$ and minimum in control whereas by the month of June the $\mathrm{N}$ concentration significantly decreased and maintained between 1.56 and 2.11 percent $\left(\mathrm{T}_{5}\right)$. Similar trend was also observed for $\mathrm{P}$ and $\mathrm{K}$ content of leaf. The highest phosphors content was measured 0.36 percent with nutrient combination 75 per cent of RDF +25 per cent FYM in the month of March and 0.18 percent with fully inorganic nutrient in the month of June. The maximum leaf potassium content declined from $2.82\left(\mathrm{~T}_{3}\right)$ to $0.73\left(\mathrm{~T}_{2}\right)$ between March to June respectively. The decrease in the nutrient status of the leaves may be due to the utilization of the resources during the crop growth and fruit development. Critical study of result indicated that leaf nutrient status is minimum with treatment T4. It may be due to the reason that that, maximum nutrient was seems to be absorbed with 50 percent organic and 50 percent inorganic combination which is reflected as least N,P,K available during the last observation. The findings are near to the findings of Marthe et al., (2012) (Table 1-3). 
Table.1 Leaf nutrient (N, P and K) status in noni crop during growth period (March to June)

\begin{tabular}{|c|c|c|c|c|c|c|c|c|c|c|c|c|c|c|c|}
\hline \multirow[t]{2}{*}{ Treatments } & \multicolumn{5}{|c|}{ Nitrogen $(\%)$} & \multicolumn{5}{|c|}{ Phosphorus (\%) } & \multicolumn{5}{|c|}{ Potassium (\%) } \\
\hline & March & April & May & June & Avg & March & April & May & June & Avg & March & April & May & June & Avg \\
\hline$T_{1}-$ Control & 3.94 & 2.77 & 2.10 & 1.99 & 2.7 & 0.29 & 0.20 & 0.16 & 0.17 & 0.20 & 2.47 & 1.27 & 0.83 & 0.41 & 1.245 \\
\hline $\mathrm{T}_{2}-\mathbf{1 0 0 \%} \mathrm{NPK}$ & 4.06 & 3.19 & 2.17 & 2.02 & 2.86 & 0.32 & 0.20 & 0.16 & 0.18 & 0.21 & 2.50 & 1.44 & 0.84 & 0.73 & 1.4 \\
\hline $\mathrm{T}_{3^{-}} \mathbf{7 5} \% \mathrm{NPK}+25 \% \mathrm{FYM}$ & 4.64 & 3.08 & 2.19 & 1.69 & 2.9 & 0.36 & 0.26 & 0.17 & 0.16 & 0.237 & 2.82 & 1.74 & 0.88 & 0.60 & 1.51 \\
\hline $\mathrm{T}_{4}-50 \% \mathrm{NPK}+50 \% \mathrm{FYM}$ & 4.68 & 3.19 & 2.25 & 1.56 & 2.92 & 0.29 & 0.25 & 0.12 & 0.12 & 0.19 & 2.32 & 1.70 & 0.92 & 0.52 & 1.365 \\
\hline $\mathrm{T}_{5}-25 \% \mathrm{NPK}+75 \% \mathrm{FYM}$ & 4.80 & 3.35 & 2.19 & 2.11 & 3.112 & 0.30 & 0.23 & 0.14 & 0.14 & 0.20 & 2.72 & 1.66 & 0.54 & 0.56 & 1.37 \\
\hline $\begin{array}{l}\mathrm{T}_{6}-100 \% \text { NPK from } \\
\text { organic (FYM, GM \& BFs) }\end{array}$ & 4.79 & 3.59 & 1.90 & 1.90 & 3.045 & 0.28 & 0.28 & 0.15 & 0.14 & 0.21 & 2.43 & 2.00 & 0.44 & 0.61 & 1.37 \\
\hline $\begin{array}{l}\mathrm{T}_{7}-100 \% \text { NPK from } \\
\text { organic (FYM, GM \& VC) }\end{array}$ & 4.77 & 2.55 & 1.85 & 1.70 & 2.717 & 0.32 & 0.19 & 0.14 & 0.14 & 0.19 & 2.35 & 1.20 & 0.37 & 0.58 & 1.125 \\
\hline $\operatorname{SEm}( \pm)$ & 0.36 & 0.29 & 0.158 & 0.02 & & 0.012 & 0.03 & 0.015 & 0.01 & & 0.23 & 0.17 & 0.55 & 0.10 & \\
\hline$C D(p=0.05)$ & NS & NS & NS & 0.05 & & 0.035 & 0.08 & 0.46 & 0.03 & & 0.71 & 0.52 & 0.41 & 0.29 & \\
\hline
\end{tabular}

Table.2 Nutrient concentration, uptake and recovery and yield of noni fruit

\begin{tabular}{|c|c|c|c|c|c|c|c|c|c|c|c|c|c|}
\hline \multirow[t]{2}{*}{ Treatments } & \multicolumn{4}{|c|}{$\mathbf{N}$} & \multicolumn{4}{|c|}{$\mathbf{P}$} & \multicolumn{4}{|c|}{$\mathbf{K}$} & \multirow{2}{*}{$\begin{array}{l}\text { yield } \\
\text { q/ha }\end{array}$} \\
\hline & $\begin{array}{l}\text { Avg } \\
\text { Conc. } \\
(\%)\end{array}$ & $\begin{array}{l}\text { Uptake } \\
\left.\text { (kg/ha }^{1}\right)\end{array}$ & $\begin{array}{c}\text { Response } \\
(\%)\end{array}$ & $\begin{array}{c}\text { ANR } \\
(\%)\end{array}$ & $\begin{array}{l}\text { Avg Conc. } \\
(\%)\end{array}$ & $\begin{array}{l}\text { Uptake } \\
\left(\mathbf{k g} / \mathbf{h a}^{\mathbf{1}}\right)\end{array}$ & $\begin{array}{c}\text { Response } \\
(\%)\end{array}$ & $\begin{array}{c}\text { ANR } \\
(\%)\end{array}$ & $\begin{array}{c}\text { Avg } \\
\text { Conc. } \\
(\%)\end{array}$ & $\begin{array}{l}\text { Uptake } \\
\left(\mathbf{k g} / \mathbf{h a}^{1}\right)\end{array}$ & $\begin{array}{c}\text { Response } \\
(\%)\end{array}$ & $\begin{array}{c}\text { ANR } \\
(\%)\end{array}$ & \\
\hline$T_{1}-$ Control & 1.90 & 18.1 & ---- & --- & 0.26 & 2.5 & ------ & --- & 1.99 & 19.0 & --- & --- & 57.5 \\
\hline $\mathrm{T}_{2}-100 \%$ NPK & 2.04 & 22.4 & 24 & 6.6 & 0.28 & 3.1 & 24 & 8.0 & 2.0 & 22.0 & 16 & 11.0 & 77.4 \\
\hline $\mathrm{T}_{3^{-}} \mathbf{7 5} \% \mathrm{NPK}+25 \%$ FYM & 2.07 & 26.3 & 45 & 16.7 & 0.28 & 3.5 & 40 & 17.8 & 2.20 & 28 & 47 & 43.7 & 84.6 \\
\hline $\mathrm{T}_{4}-50 \% \mathrm{NPK}+\mathbf{5 0} \% \mathrm{FYM}$ & 2.16 & 28.4 & 57 & 31.7 & 0.30 & 3.9 & 56 & 36.8 & 2.28 & 30.0 & 58 & 80.5 & 87.59 \\
\hline $\mathrm{T}_{5}-25 \% \mathrm{NPK}+75 \% \mathrm{FYM}$ & 2.06 & 28 & 54 & 60.7 & 0.29 & 3.8 & 52 & 68.4 & 2.18 & 29.0 & 52 & 146.4 & 82.4 \\
\hline $\begin{array}{l}\mathrm{T}_{6}-100 \% \text { NPK from organic } \\
\text { (FYM, GM \& BFs) }\end{array}$ & 2.02 & 25 & 38 & --- & 0.29 & 3.4 & 36 & --- & 2.13 & 25.1 & 32 & -- & 66.8 \\
\hline $\begin{array}{l}\mathrm{T}_{7}-100 \% \text { NPK from organic } \\
\text { (FYM, GM \& VC) }\end{array}$ & 1.93 & 21.4 & 18 & ---- & 0.28 & 2.9 & 16 & --- & 2.09 & 22.2 & 17 & --- & 61.8 \\
\hline SEm $( \pm)$ & --- & 0.163 & --- & --- & --- & 0.123 & -- & --- & --- & 0.131 & -- & -- & 0.16 \\
\hline $\mathrm{CD}(\mathrm{p}=0.05)$ & --- & --- & --- & --- & --- & 0.365 & -- & ---- & --- & 0.391 & --- & -- & 0.47 \\
\hline
\end{tabular}


Int.J.Curr.Microbiol.App.Sci (2018) 7(5): 235-240

Table.3 Initial soil status and available nutrient status in post-harvest soil

\begin{tabular}{|c|c|c|c|c|c|}
\hline \multirow[t]{2}{*}{ Treatments } & \multirow[t]{2}{*}{ pH $(1: 2.5)$} & \multirow{2}{*}{$\begin{array}{l}\text { Organic carbon } \\
\left.\text { (gkg }^{-1}\right)\end{array}$} & \multicolumn{3}{|c|}{ Available nutrient (kgha $\left.{ }^{-1}\right)$} \\
\hline & & & $\mathbf{N}$ & $\mathbf{P}$ & $\mathbf{K}$ \\
\hline $\mathrm{T}_{1}-$ Control & 5.57 & 5.52 & 84 & 33 & 201 \\
\hline $\mathrm{T}_{2}-100 \% \mathrm{NPK}$ & 5.38 & 4.9 & 163 & 84 & 320 \\
\hline $\begin{array}{l}\mathrm{T}_{3-} \mathbf{7 5} \% \mathrm{NPK}+25 \% \\
\text { FYM }\end{array}$ & 5.45 & 4.8 & 149 & 82 & 290 \\
\hline $\begin{array}{l}\mathrm{T}_{4}-\mathbf{5 0} \% \mathrm{NPK}+\mathbf{5 0} \% \\
\text { FYM }\end{array}$ & 5.28 & 4.9 & 145 & 78 & 303 \\
\hline $\begin{array}{l}\mathrm{T}_{5}-25 \% \mathrm{NPK}+\mathbf{7 5} \% \\
\text { FYM }\end{array}$ & 6.09 & 4.9 & 136 & 75 & 315 \\
\hline $\begin{array}{l}\mathrm{T}_{6}-100 \% \text { NPK from } \\
\text { organic (FYM, GM \& } \\
\text { BFs) }\end{array}$ & 6.10 & 4.9 & 132 & 72.5 & 255 \\
\hline $\begin{array}{l}\text { T }-100 \% \text { NPK from } \\
\text { organic (FYM, GM \& } \\
\text { VC) }\end{array}$ & 6.11 & 5.3 & 139 & 60.5 & 293 \\
\hline $\operatorname{SEm}( \pm)$ & & 0.27 & 4.19 & 16.37 & 3.19 \\
\hline$C D(p=0.05)$ & & 0.80 & 12.43 & 48.62 & 9.47 \\
\hline Initial status & 5.99 & 4.4 & 88 & 40 & 206 \\
\hline
\end{tabular}


The nutrient concentration in fruit produced out of different nutrient management practices ranged significantly from 1.90 to 2.16 per cent. Such N concentration in fruit resulted in uptake ranging from 18.1 to $28.4 \mathrm{~kg} \mathrm{ha}^{-1}$, lowest due to control and highest due to $50 \%$ NPK and $50 \%$ organics. The response of INM combination to $\mathrm{N}$ uptake through fruit increased from 18 to 15 per cent lowest due to $\mathrm{GM}+\mathrm{VC}+\mathrm{FYM}$ and highest due to $50 \% \mathrm{NPK}$ $+50 \%$ organic.

The $\mathrm{P}$ and $\mathrm{K}$ concentration of noni fruit ranged from 0.26 to 0.30 and 1.99 to 2.38 per cent respectively. Such $\mathrm{P}$ and $\mathrm{K}$ conc. in fruit resulted in uptake ranged from 2.5 to $3.9 \mathrm{~kg}$ $\mathrm{ha}^{-1}$ and 19 to $30 \mathrm{~kg} \mathrm{ha}^{-1}$ respectively, lowest due to control and highest due to $50 \%$ NPK and $50 \%$ organics. As a response of integrated nutrient management $\mathrm{P}$ uptake through fruit was 16 to 56 per cent lowest with $\mathrm{T} 7$ and highest in $\mathrm{T} 4$ whereas $\mathrm{K}$ uptake through fruit increased from 16 to 56 per cent, minimum due to 100 per cent inorganic and maximum with T4. Such nutritional improvements have resulted in significantly higher yield. The apparent recovery of added in organic $\mathrm{N}, \mathrm{P}$ and $\mathrm{K}$ increased from 6.6 per cent to 60.7 per cent with decreased proportion of inorganic sources. The pure organic treatments recorded lower values for compared to completely in organic or different levels of integration. The reason is being the slow rate of release of nutrients through mineralization process.

The result indicated that per hector fruit yield of the noni crop under differential nutrient management practices varied from 57.5 to $87.59 \mathrm{q} \mathrm{ha}^{-1}$. The maximum total yield was recorded with the 50 percent inorganic and 50 percent organic combination which might be due to the maximum uptake of nutrient in this vary treatment and maximum uses of nutrient from leaf. The increase in both number and weight of fruits might be due to better accumulation of the nutrient and increase in assimilating area which improved the portioning to the economic part and hence improved yield as described by Dalal et al., (2004) in sapota. Similar result was also obtained by Shivakumar et al., (2012) in papaya.

The result indicated that, the soil was initially acidic in nature. The acidity was increased ( $\mathrm{pH}$ reduced) in the post-harvest soil in control and major inorganic combinations. (5.38 in purely inorganic). The $\mathrm{pH}$ enhanced with enhancement of organic nutrition. The decline in $\mathrm{pH}$ may be due to the removal of basic cations like $\mathrm{Ca}^{2+}, \mathrm{Mg}^{2+}$ and $\mathrm{K}^{+}$which turned the soil more acidic as compared to initial state. Maintenance of higher organic carbon status in post-harvest soil due to its addition through leaf litters, manuring and maintenance of soil moisture and less intercultural operations which may be reduced the oxidation of the carbon. Soil carbon and $\mathrm{pH}$ of the soil noticed to be higher in the treatment where vermicompost was used as a part of nutrient combination. Vermicompost has a larger particulate area with a high porosity, aeration, drainage, and waterholding capacity and microbial activity, which are stabilized by interactions between earthworms and microorganisms and it mostly content the nutrient in available form so helps the crop in a non-thermophilic process.

The initial status of soil available nitrogen was $88 \mathrm{kgha}^{-1}$. The post-harvest available nitrogen status of soil varied between $84 \mathrm{~kg}$ $\mathrm{ha}^{-1}$ in $\mathrm{T} 1$ to $163 \mathrm{~kg} \mathrm{ha}^{-1}$ in $\mathrm{T} 2$. The increase in available nitrogen status of soil by annual harvest of crop. Similarly the available phosphorus and potassium in the soil initially $40 \mathrm{~kg} \mathrm{ha}^{-1}$ and $206 \mathrm{~kg} \mathrm{ha}^{-1}$. As the $\mathrm{P}$ was less utilized there is a slight increase in $\mathrm{P}$ status after addition of recommended dose of manure and fertilizers except in the control. Except in control treatment the available $\mathrm{K}$ 
status in the soil under inputs addition had increased, irrespective of these sources added (inorganic/organic).

Organic manure has chelate activity and so the release rate or mineralization is slower than the chemical fertilizer and it helps in improving the soil physical properties. Inorganic nutrient or organic nutrient in alone effect the crop but proper combination of both the types helps improving the nutrient uptake and allocation of nutrient for better growth and improvement of yield. The nutrient combination of 50 percent inorganic and 50 per cent organic proves best over all the other combinations and control and hence should recommended.

\section{References}

Dalal S R, Gonge V S, Jogdande ND, Moharia A. 2004. Response of different level of nutrients and PSB on fruit yield and economics of sapota. PKV Res. J. 28: $126-128$

Marathe, R A., Bharmbe, P R., Sharma R and Sharma U C. 2012. Leaf nutrient composition, its correlation with yield and quality of sweet orange of central India. Indian Journal of Horticulture. 69(3): 317-321.

Mosa, W.F.A.E.-G., Paszt, L.S. and ELMegeed, N.A.A. (2014) The Role of Bio-Fertilization in Improving Fruit Productivity -A Review. Advances in Microbiology, 4, 1057-1064.

Shivakumar B. S., Dharmatti P. R. and Channal H. T. 2012. Effect of organic cultivation of papaya on yield, economics and soil nutrient status. Karnataka J. Agric. Sci., 25 (4): (488492).

Singh D R, Sudha R, Pandey V B, Jayakumar $\mathrm{V}$, Srivastava R C and Damodaran T. 2007. Influence of Noni (Morinda citrifolia L.) herbal extracts on growth and production of chillies, Capsicum annum var. Arka Lohit-Souvenir and Abstacts- Noni Seach 2007:39

Zhang, S., Z.W., Watanabe, T., Nakatsuka, H., Matsuda-Inoguch, N., Higashikawa, K. and Ikeda, M. (2001) Cadmium and Lead Contents in Rice and Other Cereal Products in Japan in 1998-2000. Science of the Total Environment, 281, 165-175.

\section{How to cite this article:}

Sarat Chandra Sahoo, Jinita Barwa, Gopa Mishra and Susant Kumar Pattanik. 2018. PhysicoChemical Properties of Soil as Influenced by Integrated Nutrient Management in Noni (Morinda citrifolia), Grown as a Mixed Crop in Coconut Garden. Int.J.Curr.Microbiol.App.Sci. 7(05): 235-240. doi: https://doi.org/10.20546/ijcmas.2018.705.030 